\title{
TRANSFORMATION OF LEGISLATION ON LOCAL ELECTIONS IN DEMOCRATIC PROCESSES IN UKRAINE
}

\author{
Serhii Sergov \\ Postgraduate Student, National Academy of Public Administration \\ under the President of Ukraine, Ukraine \\ e-mail: sergovsergij@gmail.com,orcid.org/0000-0003-0191-0201
}

\section{Summary}

The article covers the transformation process of the legislation on local elections in Ukraine. It is mentioned that democratic elections are an important component of democratic transformations in the country as a whole, so it is important to conduct the search for the optimal model of the electoral system. However, the constant change of game rules in the electoral field may be evidence of manipulation and use of electoral procedures in favor of those in power and seeking to preserve their status.

Any transformations and reforms provide systemic and consistent changes. At least the party and judicial systems need to be improved in conjunction with changes to the election legislation. Party system needs to be improved because functionally parties should act as agents of political socialization, as well as recruit staff and form a political elite. Judicial system needs to be improved because each subject of the election process must have confidence in protection of their rights in case of their violation and have the ability to defend against abuse of power, fraud, corruption etc. Political education is also needed as a basis for raising the level of political culture and consciousness of society.

Keywords: local self-government, democracy, elections, political parties, electoral system, legislation.

DOI: https://doi.org/10.23856/4425

\section{Introduction}

Elections to the local self-government bodies are one of the defining democratic processes in the country. The modern election system must conform to the principles of democracy, transparency and legality, and facilitate competition that ensures the quality of the political elite. Elections are the only way to form local self-government bodies that have the right to act on behalf of the community and have the power to approve common binding resolutions in the corresponding area. It is relevant for Ukraine to improve the election system in a way which would correspond to the current level of democratic countries and take into account historical, cultural, economic, political and other national features. At the same time, changing the election rules too often is a pressing issue, since it obstructs the understanding of these rules by subjects of the electoral process.

\section{Analysis of recent research and publications}

The topic of constitutional and legal foundation of holding local elections in Ukraine has been reflected in the scientific works of such national scientists as V. Burdiak, M. Koziubra, Y. Kliuchkovskyi, R. Maksakova, O. Martseliak, V. Pakhalok, V. Pohorilko, M. Smokovych, M. Stavniichuk, V. Fedorenko and others. 


\section{Highlight of previously unsolved parts of the overall problem}

However, the mentioned scientific works do not summarize the complete experience of transforming the legislation on local elections, and neither do they draw conclusions on the practicability and effectiveness of constant changes to the election rules and procedures in the context of democratic transformations in the country.

\section{The purpose of the article}

Based on the above, we set a goal of summarizing the complete experience of transforming the legislation on local elections and a goal of drawing conclusions on the practicability and effectiveness of constant changes to the election rules and procedures in the context of democratic transformations in the country.

\section{Presenting the main material}

G. Sartori wrote that the electoral system is the institution that is the most prone to being used with manipulative intent (Sartori, 2001). This can be concluded by analyzing how many times and when the election legislation in Ukraine had been changed. It had been changed on the eve of each subsequent election in Ukraine, which is unacceptable in terms of law, morality and common sense, however it had always been justified as being politically appropriate. It should be mentioned that passing electoral laws on the eve of the election contradicts the international election standards and practices proposed by the Venice Commission, according to which such legislation must not be changed during time period of less than a year before the election day.

It is worth acknowledging that the constant change of electoral legislation will not fundamentally change the functioning nature of the electoral institution. Conversely, it may hinder the development of the order and procedure of the election process. Constant innovations can lead to misunderstanding of many rules by both commission members and citizens.

The 1994 local elections were the first local elections in Ukraine. They took place on June 26, 1994 and took place simultaneously with the snap elections of the President of Ukraine. Local elections of 1994 were held based on the Law of Ukraine "On elections of deputies and chairmen of village, settlement, district, city, district councils in cities, regional Councils" on February 24, 1994 № 3996-XII (1994, February 24).

The typical features of these elections include: 1) local council chairmen (except for heads of district councils in cities) were elected directly by voters; 2) nomination of candidates was carried out by voters both directly at the meeting (assembly) of citizens and through political parties, movements, their electoral blocs, public organizations registered in accordance with the law, and labor collectives; 3 ) a deputy candidate who received the largest number of votes from the voters who took part in the voting process compared to other candidates, but not less than $10 \%$ of registered voters, was considered elected; 4) a candidate for the Chairman of the Council was considered elected in compliance with the requirements for a candidate for deputy, provided that at least $25 \%$ of registered voters voted for him; 5) elections were considered conducted if more than $50 \%$ of the total number of registered voters participated.

The 1998 local elections were held according to the new law "On Elections of Deputies of Local Councils and Village, Town, and City Mayors", which was passed on January 14, 1998. Political parties, public organizations, and, importantly, self-nominated candidates were given 
the right to participate in elections, which became quite a positive improvement in Ukrainian electoral legislation. The results of the 1998 local elections gave a serious impulse for comprehending the new role of political parties and formation of a democratic system of politically responsible local self-governing (1998, January 14).

The 2002 local elections highlighted the problem that consciously had not been resolved in the previous years and did not get resolved in the following 2006 election year, namely the simultaneous holding of local elections and the elections of People's Deputies of Ukraine. Voters were dissatisfied with the simultaneous holding of two such important events due to the difficulty of monitoring the election campaign on two levels at the same time. Simultaneity of the elections was also negatively perceived by members of district election commissions, who had to work under heavy workloads. A considerable amount of documentation, responsibility even in case of a mistake or inattentiveness, working several nights in a row, counting four, and in rural areas five different ballots affected physical and moral conditions of both members and chairmen of election committee, which often made re-count of the votes necessary.

The 2002 regular local elections were held according to the electoral system that was used in the previous local elections: 1) elections of deputies of the village, settlement, city councils and district councils in the city, village, settlement, city mayors, as well as deputies of the Verkhovna Rada of the ARC were held according to the majoritarian electoral system of relative majority in single-member electoral districts; 2) deputy elections of district and regional councils were held according to the majoritarian electoral system of relative majority in multi-member electoral districts.

The 2006 local elections were held according to the law "On Elections of Deputies to the Verkhovna Rada of the Autonomous Republic of Crimea, Local Councils and Village, Town, and City Mayors" that was passed by the Verkhovna Rada of Ukraine on April 6, 2004 which differed significantly from previous laws. Mainly because local elections were organized according to one law, which regulated all their types, unified election procedures, which had a positive impact on the organization and holding of elections. Change of the electoral system and the introduction of a new system of forming district election commissions became novel laws. The law did not separate holding of the parliamentary and local elections in time (Maksakova, 2006:87).

The law introduced a proportional electoral system according to which deputy elections of district councils in cities, city, district, regional councils, the Verkhovna Rada of the Autonomous Republic of Crimea were held with voting for voter lists from local party organizations (blocs) in multi-member electoral districts, the borders of which matched the borders of corresponding district in the city, city, district, region, the Verkhovna Rada of the Autonomous Republic of Crimea. Article 74 of the Law provided that the right to participate in the distribution of deputy mandates would be given to local party organizations (blocs) that achieved the $3 \%$ electoral threshold, and unallocated mandates would get distributed according to the largest remainder method between parties and blocs that achieved the electoral threshold (Maksakova, 2006:88).

Dualism of the electoral systems used during the elections can be considered one of the problematic issues of the 2006 elections. Voters were put in circumstances where they elected deputies to different local self-government bodies simultaneously, but in different ways. Voters had to learn all the intricacies of the electoral system, which was quite difficult, and in turn led to complications in making a confident and conscious choice.

Next regular local elections took place on October 31, 2010. The elections were held based on the Law of Ukraine "On the Deputy Elections of the Verkhovna Rada of the 
Autonomous Republic of Crimea, Local Councils and Village, Town and City Mayors" of July 10, 2010 № 2487-VI (2010, July 10). These local elections had a similar situation with their date of holding as the regular presidential election of 2010, in that it was postponed several times. Specifically, the elections were originally set for May 30, 2010, later it was suggested to hold the elections on March 27, 2011, but October 31, 2010 became the final date. The biggest stumbling block in setting the date of local elections were different terms of authority of village, settlement and city mayors (4-year term - had not been changed) and local councils ( 5 -year term - had been increased by 1 year), which was introduced by amendments to the Constitution of Ukraine in 2004. As a result, it was impossible to hold elections to local councils and elections of village, settlement and city mayors at the same time.

The typical features of the 2010 regular local elections include: 1) local elections were held separately from the parliamentary elections, which was certainly an improvement, since it considerably simplified the organization of their holding and increased voters' attention to local candidates and local political party organizations; 2) the proportional electoral system of rigid lists in the election of deputies to the Verkhovna Rada of the ARC, regional councils, cities of Kyiv and Sevastopol, district, city and district councils in cities was replaced by a hybrid (majoritarian-proportional) electoral system, under which half of deputies from the general list of the corresponding council gets elected by electoral lists from local political party organizations in a multi-member electoral district, and the other half of deputies - under the majoritarian system of relative majority in single-member electoral districts; 3) deputy elections of village, settlement councils, and elections of village, settlement, city mayors were left unchanged and were held according to the majoritarian electoral system of relative majority in one single-member district; 4) the term of the election process has been shortened almost by half from 90 to 50 days; 5) the role of the Central Election Commission in carrying out the election process in local elections was considerably reinforced.

Although the subsequent change of voting model was caused by the imperfection of the previous proportional model but unfortunately it did not become a significant step forward in the development of municipal government. The goals of expanding the role of political parties in the management of local affairs and increasing their responsibility have not been achieved.

In contrast to previous election laws, The Law on the 2010 Local Elections did not provide for the possibility of declaring a particular type of local election invalid. It was only possible to declare voting in individual election commissions invalid, but not in the corresponding type of local elections. This meant that regardless of the number of cleared voters during the election process and during the voting, the number and percentage of polling place where voting was declared invalid, local elections are considered conducted.

The prohibition against participating of slates (political party blocs) in elections should be included in the features of the new law. The mentioned norm was an advantage first and foremost for powerful political parties while small party structures were put into a virtually hopeless situation. Besides, no changes were made to the process of electing community chairmen which were elected by the relative majority principle.

A considerable disadvantage was the norm that political parties were determined as the only subject of nomination of candidates in majority districts, as well as chairmen candidates. The norm on revocation of right to participate in the process of forming election commissions of non-parliamentary groups seemed controversial organization-wise.

On July 14, 2015, the Verkhovna Rada of Ukraine passed the Law "On Local Elections", which came into force on August 8, 2015 (2015, July 14). The mentioned law provided that the deputy elections to village and settlement councils would be held according to the majoritarian 
system of relative majority, and deputy elections to oblast, district, city councils, and district councils in cities would be held according to the proportional electoral system. Mayor elections in cities where the number of voters is greater than or equal to 90 thousand, are held according to the majoritarian system of absolute majority (i.e., in two rounds if no candidate receives more than $50 \%$ of votes in the first round). Elections of village, settlement, city mayors where the number of voters is less than 90 thousand, are held according to the majoritarian system of relative majority i.e., in one round.

The law on local elections also included the following innovations: electoral threshold for political parties equaled 5\%; slates are not able to participate in local elections; community organizations can be election observers; the number of deputies in councils had been reduced.

The Law defines the general membership (number of deputies) of a local council in relation to the number of voters. The minimum number of council deputies is 12 with the number of voters up to 1 thousand, the maximum is 120 deputies with the number of voters greater than 2 million. The law also provides the establishment of gender quotas in the list of deputy candidates for local elections. The party list must include at least $30 \%$ of same-gender members.

The ballot paper must indicate two candidates next to the name of the party: the first person is the general leader of the list, who will be indicated in all ballots in all districts (in case of the party winning the election he is guaranteed to become a deputy); the second person is assigned to a specific district (nomination in each district is not compulsory). Voters will simultaneously vote with one tick for the party, the leader of the list, and the candidate in the district, if one was nominated by the party.

In assessing the strong and weak points of the new law on local elections, experts have recognized the advantage of implementing two-round mayor elections in large cities, while the complexity of the election process and procedures has been named the main flaw of the passed law. Some experts have mentioned the constraint on opportunities for small parties and self-nominees, as well as the right of parties to nominate only one candidate per electoral district being the limit of the implemented "open lists" principle.

Despite the implementation of starosta as the new elected local government official, such elections were not held on October 25, 2015.

The beginning of the election process of the first elections of deputies of village, settlement, city councils and united territorial hromadas, and corresponding mayors started on September 9, 2017 and the first elections were held on October 29, 2017.

The 2020 local elections in Ukraine were not ordinary for the country. Firstly, because they were held during a pandemic and the voters had already got tired of politics. It could be considered that this factor influenced the low voter attendance: $37 \%$ in the first round, $29 \%$ in the second round, but this is within global trends: almost everywhere the voters are less interested in local elections than in the state elections, and attendance is always higher in the first round than in the second one.

The new Electoral Code came into force, which had its rules were rewritten close to the election date, confusing both candidates and voters.

Elections to city, district, village and settlement councils in settlements with less than 10 thousand voters were held according to the majoritarian system of relative majority, as before. Two to four deputies could be elected in one district.

The same way village, settlement, city mayors and village starostas of settlements with less than 10 thousand voters were elected according to the majoritarian system of relative majority. 
Mayors in settlements with more than 10 thousand voters were elected according to the majoritarian system of absolute majority.

Furthermore, the Electoral Code implemented a system of open lists for settlements with more than 10 thousand voters. The same system was used in deputy elections of district, district councils in cities, city, village and settlement councils with appropriate number of voters, as well as to oblast councils. Only political parties had the authority to nominate candidates. While compiling the lists of candidates the parties had to maintain a gender balance of at least $40 \%$ of members of the same sex.

The passing threshold is $5 \%$. The first candidate in the list is guaranteed to receive a deputy mandate. Candidates who obtained $25 \%$ of the electoral vote quota in their district or more are placed at the beginning of the list according to the number of votes for them in descending order. In case of obtaining equal number of votes, the order of candidates will remain as determined by the party at the time of voting. After the candidates who have passed to the council by quota, the rest of the candidates are placed in the order determined by the party.

Since United territorial hromadas were formed and oblast districts expanded as a result of the administrative reform in Ukraine, the number of local councils decreased. Thus, the total number of deputies also decreased.

The Electoral Code has kept the right of candidates to be nominated simultaneously as city, village or settlement mayors and as deputies of oblast councils, city councils and district councils. But now the candidate can be nominated to no more than two councils. Candidates for city mayors of cities with more than 75 thousand voters are allowed to be simultaneously nominated only to the city council, and the district or regional level council is unavailable for them.

\section{Conclusion}

Ukraine's legislation on local elections has been constantly changing over the last 30 years. Various electoral systems were used: majoritarian (absolute and relative majority in single-member and multi-member districts), proportional and parallel combining elements of majoritarian and proportional systems. A typical feature of elections in Ukraine are changes of electoral legislation on the eve of their holding. Moreover, most of these changes are not aimed at improvement of the electoral system, but at getting additional competitive advantages for the initiators of these changes who develop electoral technologies according to the planned innovations in advance. So, the electoral system of Ukraine is traditionally the object of applying electoral engineering technologies which are considered the means of adapting the most important electoral procedures for the effective realization of the interests of ruling elite concerning conquering and/or keeping political authority in the country, region, city, etc. (Bebyk, 2001:68). Such conclusions are nothing new, but are still relevant, unfortunately.

Any transformations and reforms provide systemic and consistent changes. At least the party and judicial systems need to be improved in conjunction with changes to the election legislation. Party system needs to be improved because functionally parties should act as agents of political socialization, as well as recruit staff and form a political elite. Judicial system needs to be improved because each subject of the election process must have confidence in protection of their rights in case of their violation and have the ability to defend against abuse of power, fraud, corruption etc. Political education is also needed as a basis for raising the level of political culture and consciousness of society. 


\section{References}

Bebyk V. M. (2001) Menedzhment vyborchoi kampanii: resursy, tekhnolohii, marketynh. [Management of the election campaign: resources, technology, marketing]. Kyiv. 216 p. [in Ukrainian].

Maksakova R. T. (2006) Osoblyvosti orhanizatsii ta provedennia mistsevykh vyboriv 2006 roku $v$ Ukraini [Features of the organization and conduct of local elections in 2006 in Ukraine] Visnyk TsVK-Bulletin of the CEC. № 2 (4). P. 86-91 [in Ukrainian].

Novyi Vyborchyi kodeks: yak budut provodyty mistsevi vybory [New Electoral Code: how local elections will be held]. Retrieved from https://www.slovoidilo.ua/2020/01/14/infografika/polityka/novyj-vyborchyj-kodeks-yak-budut-provodyty-miscevi-vybory [in Ukrainian].

Pro vybory deputativ Verkhovnoyi Rady Avtonomnoyi Respubliky Krym, mistsevykh rad ta sil's'kykh, selyshchnykh, mis'kykh holiv: Zakon Ukrayiny vid 6 kvitnia 2004 № 1667-IV [On the election of deputies of the Verkhovna Rada of the Autonomous Republic of Crimea, local councils and village, settlement, city mayors: Law of Ukraine dated April 6, 2004 № 1667-IV] Retrieved from https://zakon.rada.gov.ua/laws/show/1667-15\#Text [in Ukrainian].

Pro vybory deputativ Verkhovnoyi Rady Avtonomnoyi Respubliky Krym, mistsevykh rad ta sil's'kykh, selyshchnykh, mis'kykh holiv: Zakon Ukrayiny vid 10 lypnya 2010 roku № 2487-VI [On the election of deputies of the Verkhovna Rada of the Autonomous Republic of Crimea, local councils and village, settlement, city mayors: Law of Ukraine dated July 10, 2010 № 2487-VI]. (2010, July 10) Vidomosti Verkhovnoyi Rady Ukrayiny - Bulletin of Verkhovna Rada of Ukraine. Kyiv: Parlam. vyd-vo [in Ukrainian].

Pro vybory deputativ i holiv sil's'kykh, selyshchnykh, rayonnykh, mis'kykh, rayonnykh u mistakh, oblasnykh Rad: Zakon Ukrayiny vid 24 lyutoho 1994 roku № 3996- XII [On the elections of deputies and heads of village, settlement, district, city, district in cities, regional councils: Law of Ukraine dated February 24, 1994 № 3996-XII]. (1994, February 24). Vidomosti Verkhovnoyi Rady Ukrayiny - Bulletin of Verkhovna Rada of Ukraine. Kyiv: Parlam. vyd-vo [in Ukrainian]. Pro vybory deputativ mistsevykh rad ta sil's'kykh, selyshchnykh, mis'kykh holiv: Zakon Ukrayiny vid 14 sichnya 1998 roku № 14/98-VR [On the elections of deputies of local councils and village, settlement, city mayors: Law of Ukraine from January 14, 1998 № 14/98-BP]. (1998, January 14). Vidomosti Verkhovnoyi Rady Ukrayiny - Bulletin of Verkhovna Rada of Ukraine. Kyiv: Parlam. vyd-vo [in Ukrainian].

Pro mistsevi vybory: Zakon Ukrayiny vid 14 lypnya 2015 roku № 595-VIII [On Local Elections: Law of Ukraine dated July 14, 2015 № 595-VIII] (2015, July 14). Vidomosti Verkhovnoyi Rady Ukrayiny - Bulletin of Verkhovna Rada of Ukraine. Kyiv: Parlam. vyd-vo [in Ukrainian].

Sartori G. (2001) Porivnialna konstytutsiina inzheneriia: doslidzhennia struktur, motyviv $i$ rezultativ [Comparative constitutional engineering: a study of structures, motives and results.]. Kyiv. 224 p. [in Ukrainian]. 